DOI: $10.14451 / 2.128 .13$

\title{
НЕКОТОРЫЕ ПРОБЛЕМЫ И ПЕРСПЕКТИВЫ ВЗАИМОДЕЙСТВИЯ ПАРЛАМЕНТА РФ С ОРГАНАМИ ГОСУДАРСТВЕННОГО УПРАВЛЕНИЯ
}

\author{
(C) 2019 Кочиева Олеся Ахсаровна \\ Председатель Верховного Суда Республики Южная Осетия \\ 100001, г. Цхинвал, ул. 13 Коммунаров, 29 \\ E-mail: 71dz@mail.ru
}

(c) 2019 Караева Лора Хазбатровна

кандидат юридических наук, доцент кафедры уголовного права и процесса Северо-Осетинский государственный университет имени К.Л. Хетагурова 362025 , г. Владикавказ, ул. Ватутина, 44-46

В настоящей статье анализируются актуальные на данный момент вопросы и возможности взаимодействия между Федеральным Собранием Российской Федерации и органами государственной власти. Также предлагаются способы развития системы разграничения властей на высшем уровне, для чего в действующем законодательстве необходимо сформировать инновационные способы взаимодействия между Правительством Российской Федерации и Государственной Думой. Рассматривается роль увеличения ответственности законодательных органов власти за современную ситуацию в стране, а также важности максимально деятельного участия Государственной Думы в реализации контроля за работой органов Правительства РФ.

Ключевые слова: Федеральное Собрание Российской Федерации, ветви власти, Президент Российской Федерации, органы государственного управления, исполнительная власть, политическая система.

Во главе нашего государства стоит Президент Российской Федерации. Он - гарант Конституции РФ, а также прав и свобод человека и гражданина. В законодательно закрепленном порядке Президент обеспечивает охрану независимости государства, целостности его границ, способствует скоординированной деятельности и взаимодействию между органами государственного управления. Также Президент устанавливает ключевые векторы развития как внутренней, так и внешней политики страны.

Существует множество смежных аспектов в правах Президента РФ и компетенциях Федерального Собрания. Главным образом это касается законотворчества, включая повторное рассмотрение вопросов, которые Президент отклонил.

Конституция РФ устанавливает основания отношений между Федеральным Собранием РФ, его палатами и Правительством РФ. Данные взаимоотношения детально регламентирует Федеральный конституционный закон «О Правительстве РФ», регламенты Совета Федерации и Государственной Думы, а также иные нормативно-правовые акты. Существенный аспект подобных взаимоотношений состоит в том, что у Правительства РФ есть право законодатель- ной инициативы через внесение проектов законов в Государственную Думу. Кроме того, у Правительства есть право на внесение поправок в законопроекты, рассматриваемые Государственной Думой. Но практика показывает, что Правительство РФ слабо проявляет инициативу в формировании законопроектов, которые отправляются на рассмотрение Государственной Думой. При этом ненадлежащим образом производится учет проектов, которые подготавливает Правительство РФ. Это происходит в связи с тем, что основная их масса рассматривается в качестве депутатских законопроектов.

Множество законопроектов в принципе превышает рамки возможности качественной деятельности Правительства. Следует отметить перегруженность повесток дня большого количества заседаний Государственной Думы. Зачастую повестка дня бывает представлена слабо разработанными вопросами, которые не только не подкреплены сопроводительной документацией, но и содержат множество грамматических ошибок.

Для того чтобы разрешить данную проблему, мы считаем, что следует закрепить требование Регламента Государственной Думы, в соответствии с которым правовые субъекты должны 
получить право законодательной инициативы наряду с предлагаемым законопроектом о внесении поправок в федеральный бюджет. Кроме того, считаем необходимым закрепить требование, согласно которому в отношении подобных законов должно проводиться пакетное рассмотрение, после чего они будут вступать в силу. Это поможет обеспечить попадание законопроекта на рассмотрение Государственной Думой лишь после приведения его содержания в соответствие с возможностями федерального бюджета РФ.

В настоящее время приходится констатировать значительное ограничение независимой и сдерживающей роли Совета Федерации в отечественной системе разграничения властей. На это указывает и тот факт, что за последние 10 лет по инициативе президента условия создания Совета Федерации подвергались изменениям три раза. Разнообразные реформы привели к почти полной утрате Советом Федерации своих конституционных полномочий. В связи с этим обеспечение автономного и независимого статуса данного органа государственного управления, активизация его взаимодействия с другими институтами государственной власти дадут возможность упрочения отечественной конструкции разграничения власти, чтобы она соответствовала республиканскому, демократическому устройству государства [1].

Тот факт, что отношения между ветвями власти по нынешней Конституции РФ, не соответствуют традиционной схеме Монтескье, говорит об их российской национальной особенности. РФ - федеративное государство, и институту президента здесь отводится основополагающая роль, которая проистекает из федеративной сущности российской государственности. На сегодняшний день есть основания полагать, что по мере того как образуются мощные парламентские партии, между которыми активизируются конкурентные взаимоотношения, отношения между Правительством и Государственной Думой могут стать кризисными. В связи с этим исключительно верхний уровень разграничения власти Президент - Совет Федерации - Конституционный Суд обеспечит в данной ситуации стабильное функционирование властных органов. Для этого необходимо совершенствовать конституционно-правовые взаимоотношения президента, в первую очередь с Советом Федерации и Конституционным Судом. Следует не вслепую перенимать зарубежную практику парламентаризма, а привести ее в соответствие с существующей отечественной структурой разграничения властей и как можно более строго закрепить роль Президента РФ в действующей схеме отечественной государственности. Необходимо, чтобы сущность провозглашенного Конституцией принципа разграничения властей отвечала требованиям современности, на которые влияют не предвыборные планы партий и уж тем более не окончание срока нынешнего Президента, а потребность в упрочении российского государства, что позволит ему выйти на качественно новый уровень развития. Для того чтобы усовершенствовать систему разграничения власти на верхнем уровне, необходимо также максимально четко зафиксировать законодательно и активизировать современные механизмы взаимодействия между Правительством и Государственной Думой. Также должна увеличиваться ответственность законодательных органов власти за политическую и экономическую в РФ, для чего требуется обеспечить максимально активное участия Государственной Думы в реализации контроля за работой органов правительства. Подобный контроль в нашей стране осуществляется сейчас не в полную силу, и этому способствует недостаточно развитая правовая основа. Мало того, в нынешней Конституции РФ отсутствуют даже нормы, регламентирующие парламентский контроль, что осложняет последующую законодательную регламентацию контрольных функций депутатского корпуса. Отчасти данную проблему регламентирует ФЗ «О парламентском расследовании Федерального Собрания РФ». Также на время, пока проводится парламентское расследование, палате Федерального Собрания можно предоставить право на создание такой должности, как специальный следователь, с целью расследовать фактов покушения государственных деятелей на основы конституционного устройства нашего государства.

Оптимизация требуется и конституционному механизму вынесения недоверия Правительству РФ Государственной Думой. Следовало подкрепить этот механизм необходимой базой (к примеру, по причине отрицательной оценки деятельности Правительства, несогласия депутатского корпуса с ключевыми направлениями политики, реализуемой Правительством) и уменьшить период в 3 месяца, на протяжении 
которого у Государственной Думы имеется право на выражение повторного недоверия Правительству РФ. Указанный срок может стать сроком противостояния между законодательной и исполнительной властью, и на протяжении этого времени возможно усугубление правительственного кризиса в связи с тем, что Государственная Дума может блокировать законодательные инициативы, выдвигаемые органами исполнительной власти, а также по причине ответного прессинга на депутатский корпус со стороны исполнительных органов власти. На данный момент для этого существует множество предпосылок. Во всяком случае, до тех пор, пока Правительство РФ является не абсолютно независимым конституционным органом, ответственным за деятельность целостной структуры исполнительной власти, а всего лишь частью института президентской власти, исполнителем волеизъявления президента. В связи с тем, что подобная организация исполнительных органов власти не совсем соответствует закрепленному Конституцией принципу разграничения власти по причине замыкания Правительства лишь на Президента и ограничения Государственной Думы, многое будет находиться в зависимости не только от личности самого президента, его компетентности в финансовых и экономических вопросах, но и от лиц, составляющих кабинет министров [2].

Следует обеспечить большее взаимодей- ствие между Правительством и Государственной Думой, причем важно, чтобы при его реализации отсутствовали чрезмерное давление и вторжение главы государства. Вторжение президента в подобные взаимоотношения можно назвать целесообразным лишь в условиях кризиса, затрагивающего не только правительство, но и парламент, если указанные взаимоотношения становятся тупиковыми. Необходимо отметить, что Президент располагает правовыми инструментами регламентации такого кризиса. Возможности же упрочения ежедневных отношений между Правительством и Государственной Думой находятся в первую очередь в законодательном секторе, где названные два института должны превратиться в главных партнеров уже на этапе законотворчества.

Более эффективному закреплению контрольных полномочий Федерального Собрания за деятельностью исполнительной власти могло бы способствовать принятие отдельного федерального закона, в котором регулировалась бы деятельность Государственной Думы и Совета Федерации. Такой закон мог бы регулировать также статус Федерального Собрания Российской Федерации, его компетенцию и вопросы ведения, структуру, организационные формы и условия его деятельности, вопросы взаимоотношений между палатами Федерального Собрания, а также различные аспекты взаимодействия с другими органами государственной власти.

\section{Библиографический список}

1. Баев А. Российский парламент // Обозреватель. 2009. № 4. С. 15-22.

2. Усанов B.E. Разделение властей как основа конституционного строя и его роль в формировании парламентаризма в современной России // Государство и право. 2015. № 12. С. 13-22. 